\title{
Modelling the demographic sustainability of pure beech plenter forests in Eastern Germany
}

\author{
Jean-Philippe ScHÜTZ* \\ Silviculturist, Brüggliäcker 37, CH 8050 Zürich, Switzerland
}

(Received 1 December 2004; accepted 30 May 2005)

\begin{abstract}
The aim of this study is to scrutinise whether a dynamic equilibrium model based on sustainability of the demography is valid for pure beech plenter forests. Broad-leaved trees in general, and beech in particular react differently to individualisation and to shade than conifers, because of differences in space occupancy and their reaction to shade. Therefore application of the plenter system (or selection system) presents other constraints than for conifers forests. Sustainability must be assessed at stand level, because the plenter system functions without cover interruption and so needs continuous recruitment growing from the stand bottom up. The algorithm used for determination of demographic equilibrium depends on knowledge of the recruitment from below, stem migration over time (dependent on diameter increment), and removal for cultural and harvesting purposes and their dependency from stand density. Data used in this study comes from three permanent research plots in the pure beech plenter forests of Langula (Thuringia basin, Eastern Germany). The determination of the optimal stand density ensuring equilibrium uses an incremental growth model based on a basal area oriented density index (GCUM). It emphasises the phenomenon of growth extinction with increasing stand closure. Equilibrium is gained for a standing volume about $250 \mathrm{~m}^{3} / \mathrm{ha}$ and Basal area $22 \mathrm{~m}^{2} / \mathrm{ha}$. This occurs at a much lower stand density than for classical coniferous plenter forests. The reasons for these differences and the silvicultural consequences are discussed.
\end{abstract}

sustainability / selection forest / uneven-aged forests / equilibrium / modelling / beech

Résumé - Modélisation de l'équilibre démographique en futaie jardinée de hêtre en Allemagne de l'Est. L'objectif de cette étude est de vérifier l'applicabilité d'un modèle d'équilibre démographique aux forêts jardinées de feuillus. Les feuillus réagissent différemment des conifères à l'individualisation due à l'irrégularité car ils utilisent différemment l'espace vital et l'ombrage. L'application des principes du jardinage est donc liée à des contraintes limitantes différentes que pour les forêts jardinées classiques de conifères. L'équilibre se détermine au niveau du peuplement, car en futaie jardinée il n'y a jamais interruption de couvert. Il faut donc une continuité du recrutement sous couvert. L'algorithme utilisé pour déterminer l'équilibre démographique se fonde sur la mesure du recrutement, de la migration des tiges dépendant de la croissance radiale et des éliminations à des fins culturales et de récolte, le tout dépendant de la densité des peuplements. Les données proviennent de trois parcelles d'essai de futaies jardinées de hêtre de Langula en Thuringe (Allemagne de l'Est). Le modèle incrémentiel de détermination de la densité optimale de peuplement qui assure l'équilibre démographique utilise un indice de densité variable GCUM fondé sur la surface terrière des plus gros. Il met en évidence un phénomène d'extinction du recrutement avec l'augmentation de la fermeture des peuplements. L'équilibre jardiné s'obtient pour des volumes sur pied de l'ordre de $250 \mathrm{~m}^{3} / \mathrm{ha}$ et une surface terrière de $22 \mathrm{~m}^{2}$, ce qui est nettement plus bas que dans le cas des forêts jardinées de conifères. On discute les raisons de cette différence et les conséquences sylvicoles.

durabilité / forêt jardinée / irrégularité /équilibre / modélisation / hêtre

\section{INTRODUCTION}

In plenter, or "selection" forests, the way to achieve, assess and control sustainability differs fundamentally from most other systems with obvious generation alternation. In this text, we use the term "plenter" because the term "selection" generally has other implications. In a plenter forest all age (or dimension) classes are closely intermixed over small areas. This means that the stem number distribution in equidistant diameter class characterise not only stand structure, but actually represents the whole life cycle, comparable to the sum of all age-classes in regular forest. It is customary to use such a distribution when analysing demographic balance. This means that sustainability must be realised on a stand scale. Because plenter forests never present crown cover interruption, renewal occurs from the stand bottom up. Therefore, assuming continuity, the way in which young trees (or recruitment) grow up from below in sufficient demographic numbers to reach the upper level is decisive. One of the main problems of this renewal process is that the deeper the trees are in the stand, the darker the shade and the more restricted condition for upgrowth. This explains why tolerance to shade is a limiting factor when considering the sustainability of plenter forests.

\footnotetext{
* Corresponding author: jph.s@bluewin.ch
} 
A demographic steady state, (such as an invariant stem number distribution) is achieved when enough ongrowth (recruitment) occurs to compensate for trees removed for harvesting. Borel [3] first defined this long-term sustainability for each stand compartment (i.e. small, medium and large timber) using a simple demographic rule: over time, the number of trees growing up from below for each compartment (ingrowth) is equal to the number growing in the upper class (outgrowth), minus removal for silvicultural purposes. This demographic equilibrium can be extended to the whole diameter class sequence and so allows the incremental calculation of a corresponding steady state stem number distribution [16, 19, 20]. Real sustainability is achieved on the further assumption that the standing volume remains constant, in other words, that the removal volume (the sum of all removed trees) is equal to the observed periodic volume increment, otherwise the standing volume changes and so all demographic relationships.

Changes in standing volume have direct effect on regeneration and recruitment. At a certain stand density threshold, recruitment is no longer sufficient to guarantee demographic continuity, and the plenter structure will decline in the long run. So finding out the recruitment ensuring equilibrium makes necessary to understand how modifications of stand density influence recruitment and demography, i.e. influence on diameter increment.

In previous studies, a dynamic incremental algorithm has been used to determine equilibrium for the classical plenter forest in Switzerland i.e. for fir (Abies alba Mill.) or spruce (Picea abies (L.) Karst) forest at mountain elevations [19-21]. It is based on:

- the diameter increment for each $d$-class $\left(i_{\mathrm{d}}\right)$ and its dependence on stand density;

- the pattern of removal in each $d$-class $\left(e_{\mathrm{i}}\right)$;

- recruitment (in stem number, at the inventory threshold, $N_{10}$ ) and its interdependence on stand density.

The aim of this study is to determine the functional prerequisites ( $d$-increment, ingrowth, removal) and the dependence on stand density, necessary to apply the model of single stem equilibrium based on demographic sustainability to pure beech plenter forests and considers the silvicultural consequences.

Broad-leaved trees in general (and beech in particular) react differently to individualisation and shade than conifers, calling their suitability for a single-tree irregular system into question $[17,23]$. The reasons for this are their different crown space occupancy and their reaction to shade. Broad-leaved species, free from lateral concurrency, expand their crowns laterally and tend to close the canopy. Therefore, for the same diameter under plenter conditions, the crowns of beech prove to be twice as large as those of spruce $[2,25]$. In addition, they react to canopy closure opening by developing a second crown from epicormic branches. Thirdly, sapling trees of species with a tendency towards sympodic branching architecture (such as beech) cannot tolerate as much shade as conifers without losing their ability to recover qualitatively (once shade is reduced), because they develop a plagiotropic branching form [24].

All these factors explain why pure beech plenter forests are very rare. They are considered to preserve their irregular structure by maintaining a relatively low stand closure, with standing volumes of about $250 \mathrm{~m}^{3} /$ ha or below $[12,19]$. This makes the plenter structure for beech more unstable than for coniferous stands. Nevertheless, essentially pure beech plenter forests do exist, especially in the Thuringia basin in Eastern Germany $[6,7,12,21]$ where they occupy about 5000 ha. In 1955, permanent research plots were established at Langula to record the yield and structure evolution of these particular forests $[7,8]$.

\subsection{The demographic equilibrium}

As stated above, demographic sustainability depends on recruitment, removal and stem migration throughout the dbhclasses over time. Demographic equilibrium is achieved if the number of trees growing up from below (ingrowth) equals the number growing in the upper class, minus removal for silvicultural purposes (selection and nurturing) and for harvesting. Essentially, tree migration throughout the $d b h$-classes is a function of growth and stem number. Over a given period of time, for instance one year, $[16,20]$ migration is given as:

(a) The product $n_{\mathrm{i}} \times p_{\mathrm{i}}$, where $p_{\mathrm{i}}$ (the outgrowth rate) is the proportion of trees at the start of the period leaving the class $i$ per year; $n_{\mathrm{i}}$ is the number of trees per diameter-class $i$. $p_{\mathrm{i}}$ depends directly on the diameter increment $i_{\mathrm{d}}$ and can be simply deduced by dividing the observed $i_{\mathrm{d}}$ (annual diameter increment) by the diameter class width. Thus, in this case ( $4 \mathrm{~cm} d$-class): $p_{\mathrm{i}}=i_{\mathrm{d}} / 40$. Considering the contiguous diameter classes $\mathrm{i}$, and $i+1$, migration into and out of class $i+1$ can easily be calculated as: coming up from below (ingrowth) $n_{\mathrm{i}} \times p_{\mathrm{i}}$, and entering the next (outgrowth) $n_{\mathrm{i}+1} \times$ $p_{\mathrm{i}+1}$.

(b) Removal: $\left(n_{\mathrm{i}} \times e_{\mathrm{i}}\right)$ where removal rate $e_{\mathrm{i}}$ is the proportion of trees from the initial number removed during the reference time span.

Thus a steady state is reached when trees moving up from below equal outgrowth plus removal. This gives us the following general demographic steady state equation:

$$
n_{\mathrm{i}} \times p_{\mathrm{i}}=\left(n_{\mathrm{i}+1} \times p_{\mathrm{i}+1}\right)+\left(n_{\mathrm{i}+1} \times e_{\mathrm{i}+1}\right)
$$

thus: starting from $n_{\mathrm{i}}$, the $n$ for the class $i+1$ could be deduced incrementally forward as:

$$
n_{\mathrm{i}+1}=n_{\mathrm{i}} \times p_{\mathrm{i}} /\left(p_{\mathrm{it} 1}+e_{\mathrm{i}+1}\right)
$$

or step by step backward as:

$$
n_{\mathrm{i}-1}=n_{\mathrm{i}} \times\left(p_{\mathrm{i}}+e_{\mathrm{i}}\right) /\left(p_{\mathrm{i}-1}\right) .
$$

So, starting with a given $N_{\min }$ (number of trees in the lowest diameter class) or $N_{\max }$ (number in the largest diameter class), the steady state tree numbers of every $d b h$-class $i$ can be modelled according to formula (2) or (3). This provides the shape (the decreasing sequence) of the steady state stem number distribution. The result is not a smooth decreasing curve, but one with different rates of decline for different diameter ranges. In the half logarithmic scale the curves generally appear as sigmoides.

In order to define the stem distribution which corresponds to sustainable equilibrium it is necessary to calibrate the modelled stem number sequence to observed growing conditions and conditionally in taking in account the relationship between stand density and growth variables (i.e. recruitment, $p_{\mathrm{i}}$ ). To do this, we scrutinize the real observed starting $N$ (the number of 
trees in class $10 \mathrm{~cm}$, hence $N_{10}$ ). This variable could be considered as the result of previous history of recruitment and as a good indicator for functional ingrowth. $N_{10}$ has to be compatible with the corresponding stand density observed. In addition it is necessary to take heed of the influence of stand density on migration (i.e. on diameter increment). In previous studies, we found that the variable GCUM (or density index from larger trees) is well suited as an incremental competition factor, because it provides competition values (more or less related to canopy closure) for each diameter class. GCUM is defined as the sum of the cross-section area of every tree larger than the considered $d$-class [16]. Its value for the lowest diameter class is equal to $G$ (basal area), which is well known as a whole stand competition indicator. GCUM is very simple to determine incrementally from the stem number distribution. GCUM is otherwise known in forest literature as BAL (basal area of larger trees, or overtopping BA) [26]. GCUM can be assessed for a distance-independent data set, thus corresponding to data regrouped per $d$-class at stand level, as well as for individual tree models, i.e. distance-dependent. It is then necessary to define a reference area. When considering shade projection from the largest trees, we can determine that a circular area of $25 \mathrm{~m}$ radius (about $0.2 \mathrm{ha}$ ) would be appropriate [25]. In this study, GCUM has been defined at $d$-class level $(4 \mathrm{~cm})$ for the corresponding stands (1 ha).

The diameter increments of classical plenter forests in Switzerland $\left(i_{\mathrm{d}}\right)$ could be explained accurately with a non-linear regression by GCUM and $d$ (diameter class) as dependent variables, with an $R^{2}$ lying between $0.83-0.87$ [18, 19, 25]. The best fitting regression for $i_{\mathrm{d}}$ is gained after log naturalis transformation of $d_{\mathrm{i}}$ and to the power of 2 or 3 for GCUM.

Removal rate $\left(e_{\mathrm{i}}\right)$ estimation is the most sensitive point in the equilibrium model. According to the rule of sustainability, the sum of removal must correspond to the whole increment (in terms of basal area increment or volume increment) otherwise the standing volume would increase and change the relationship of growth. The distribution pattern of the removal rate over the $d$-class depends on the silvicultural need for selection and nurturing in the lowest $d$-classes and on strategic aims (namely, the choice of harvesting target dimensions) in the upper part of the $d$-class. It is thus possible to generate a removal rate distribution based on silvicultural needs in the lower part and assuming aimed target dimensions in the upper part, conditionally that its sum equals the observed increment. Thus different removal strategies (in term of target dimensions) correspond to different equilibrium positions [16].

\section{MATERIALS AND METHODS}

Pure beech plenter forests with the appropriate single tree structure are extremely rare. Apart from the Thuringia basin, there are some in the Swiss Jura and French Franche-Comté but only in very scattered locations. Because of this, it was necessary to use yield data observed over a sufficiently long period of time. Data was provided from three permanent plots of the chair of forest yield, Tharandt Forestry School at the Technical University of Dresden. The reasons for the exceptional presence of about 5000 ha beech plenter forests in this region are mainly due to its previous land use (coppice with standards) and its status as a communally-owned and -utilised forest [6]. They are situated in the private Langula-Oppershausen corporative forest. There is a long-standing, well-documented tradition in this region for single
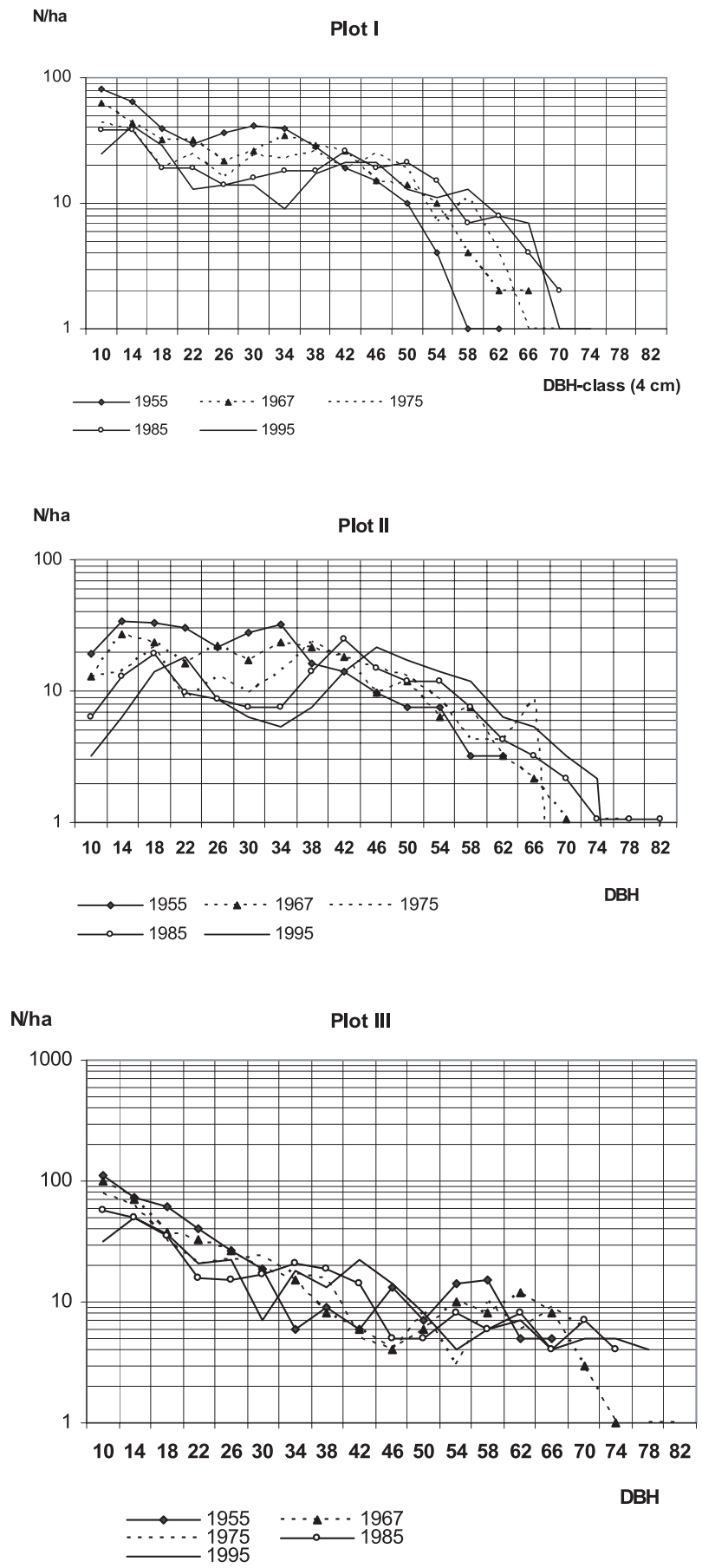

Figure 1. Distribution of stem numbers (per $4 \mathrm{~cm}$ DHB-class) of the three Langula plots (semi-logarithmic scale).

tree plentering in pure beech forests [9, 12-15]. During the era of the German Democratic Republic, this tradition was passed down by foresters from generation to generation. Plot I corresponds to a plenter structure with a relatively high standing volume and a tendency to lose vertical structure and to homogenise. Plot II corresponds at best to the expected beech plenter structure for the kind of selection system practised in this region in terms of harvest-diameter. Plot III shows the best vertical structure (Fig. 1). 
The Langula forest is situated at an elevation of about $400 \mathrm{~m}$ a.s.l. $51^{\circ} 08^{\prime} \mathrm{N}, 10^{\circ} 20^{\prime} \mathrm{E}$, at the south-western edge of the Thuringia Basin, in eastern Germany. The climate is sub-Atlantic with $720 \mathrm{~mm} / \mathrm{y}$ precipitation and an average temperature of 6.5 to $7{ }^{\circ} \mathrm{C}$. The substrate is shell limestone overlain with a loess lay of variable thickness between $0.2-1 \mathrm{~m}$. Phytosociologically it belongs to limestone pure beech forests (Cardamino-Fagetum).

Each plot has an area of about 1 ha. From a threshold of $8 \mathrm{~cm}$ on, all trees were identified with a number, and the dbh measured repeatedly after thinning in 1955, 1960, 1967, 1976, 1986 and 1995, within an accuracy of $1 \mathrm{~mm}$. Removed trees have been assessed in the same way, and the reason for their removal noted. To give a more comparable increment period, the 1960 inventory has been set aside. This provides a sample of 15 inventories ( 3 plots by 5 occasions) and 12 increment periods. Because the stem form-function used for standing volume calculation in Tharandt is derived from regular forest stands, volume has been estimated according to the local volume-function per $d b h$-class for beech from the Schallenberg-Rauchgrat plenter forest in Switzerland, based on section wise measurement of thinned beech trees. This well-known fir-spruce forest in Emmental has a significant beech admixture. In addition, there are no major climatic variations between Emmental and Thuringia. This volume-function provides a stem volume above $7 \mathrm{~cm}$ ( $\mathrm{V}_{7}$, stem volume without branches).

Removal data comes from the recorded removal rate in each $d$-class of the three plots. Because silvicultural interventions hadn't fulfilled in every case the condition of removing the whole volume increment (a prerequisite for sustainability), data has been adjusted with a simple rule of proportion, according to the whole increment. For comparison a second set of data, based on empiric experience in a Swiss beech plenter forest, has also been considered; in order to corroborate the general applicability of the Thuringian removal pattern. For classical plenter forests, a detailed analysis of interventions carried out by different silviculturists shows that relative patterns of removal rates for silvicultural purposes especially in the lower part of the distribution are very similar [16]. Since the introduction of the Control Method (around 1890), removals have been well documented in different plenter forests. For this study, the second set of removal data emanates from the well-known Les Erses private plenter forest, a forest of about 67 ha in the Swiss Jura, on an elevation of 980-1200 m a.s.1. [4], where single tree plentering bas been practised since 1889 . The data set corresponds to plentering interventions in five compartments with adequate admixture of beech, (with variations of between 19-85\%), and with a low standing volume (average $185 \mathrm{~m}^{3} / \mathrm{ha}$ with a variation of $124-258 \mathrm{~m}^{3} / \mathrm{ha}$ ). The data set encompasses 44 records of removal (from 9 periods and 5 compartments).

Over the observation period, the standing volume in the Langula plots varied from 237 to $375 \mathrm{~m}^{3} / \mathrm{ha}$. It increased particularly in Plot I. Plot II had the lowest standing volume at the start $\left(237 \mathrm{~m}^{3} / \mathrm{ha}\right)$. After an initial period of increase until 1976 (up to about $300 \mathrm{~m}^{3} / \mathrm{ha}$ ), it remained unchanged until 1985. In Plot III the volume remained constant. Such variations are appropriate for the aim of this study, as they help to determine the interdependence of stand density and increment. However, since it has been documented that standing volumes of over $300 \mathrm{~m}^{3} / \mathrm{ha}$ are too high to maintain the plenter structure [22], the final inventories of Plot I must be scrutinised particularly carefully.

For regression analysis, general regression model have been used, based on the Gauss-Newton estimation with least square fitting procedure, according to the SYSTAT (version 10.2) statistical package. Complete multiple regressions, with different transformation of the dependent variables, as well as stepwise regression with the backward procedures with successive elimination of less significant variables at a certain $t$-statistic threshold were performed. Different variable transformation has been tested: $\ln$, square, square root, arc sin. The best transformation in terms of visual fitting, residual distribution and $R^{2}$ has been retained. The explicative power of the variables is given by $F$-statistic.

$$
\mathrm{i}_{\mathrm{d}}(\mathrm{mm} / \mathrm{y})
$$

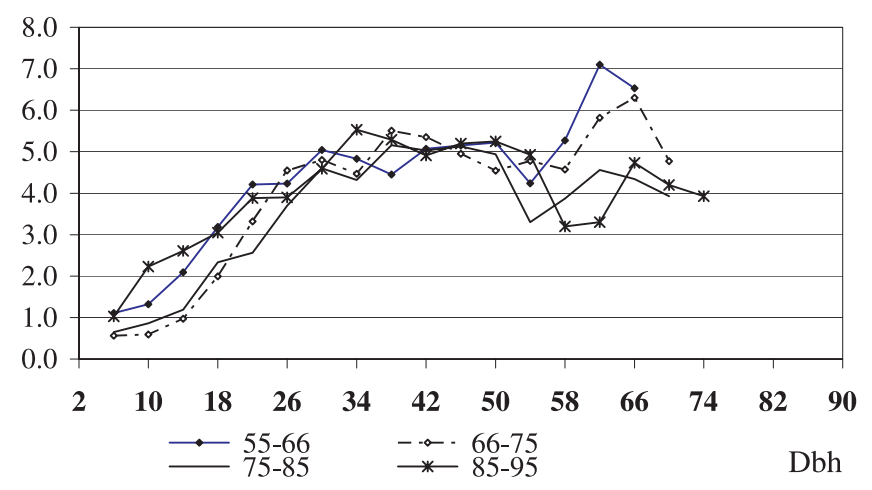

Figure 2. Diameter increment for Langula beech plenter forest in relation to $d b h$ for the four periods. Average of the three plots.

\section{RESULTS}

\subsection{Diameter increment}

Figures 2 and 3 depict the diameter increment course $\left(i_{\mathrm{d}}\right)$ of the different $d$-classes $(4 \mathrm{~cm})$ at Langula, against dbh respectively GCUM for the four periods.

The diameter increment $\left(i_{\mathrm{d}}\right)$ can be estimated accurately with the two estimators diameter class $\left(d_{\mathrm{i}}\right)$ and density index (GCUM). The best regression is given with ln-transformation for $d_{\mathrm{i}}$ and to the power of 3 for GCUM. Introduction of GCUM proves to ameliorate significantly the estimation. This is consistent with previous observations in coniferous plenter forests and can be explained by the fact that GCUM depicts stand closure differences. The sharp decrease of $i_{\mathrm{d}}$ with increasing stand closure (GCUM) for trees in the lower part of the stand is particularly interesting. This trend depicts a form of growth extinction or growth limit for recruitment. The intercept with the $\mathrm{x}$-axis is akin to a threshold for carrying recruitment capacity.

An analysis of variance in a stepwise multiple regression with $d_{\mathrm{i}}$ and GCUM as continuous independent variables, as

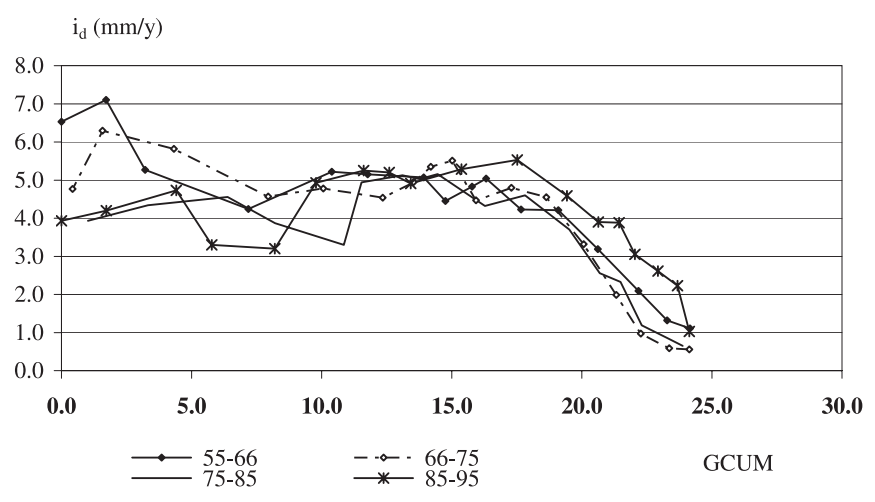

Figure 3. Diameter increment for Langula beech plenter forest in relation to density index GCUM for the four periods. Average of the three plots. 
$\mathrm{i}_{\mathrm{d}}(\mathrm{mm} / \mathrm{y})$

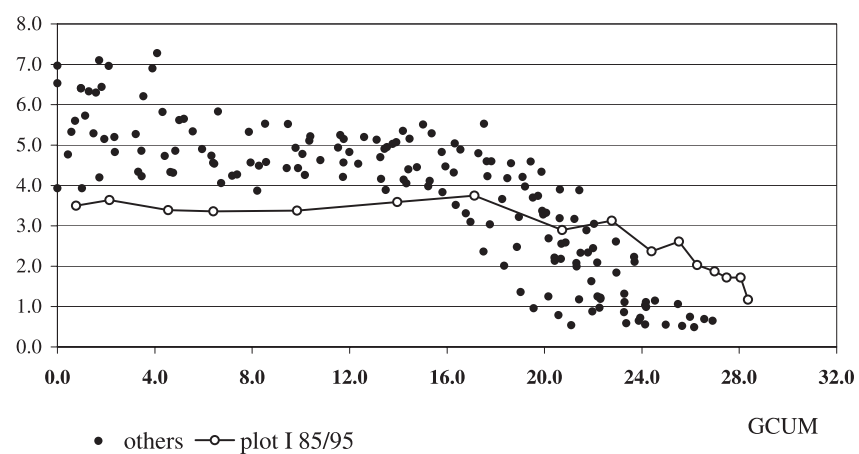

Figure 4. Diameter increment in relation to GCUM for the Langula plots with enhancement of the abnormal behaviour of Plot I for the last period (85/95).

well as inventories and plots as categorical variables (results not shown) indicates a significant interaction of both plots and increment period. The somewhat abnormal results of the $85 / 95$ Plot I inventory (see Fig. 4) can be explained by the fact that the standing volume was too high and influence diameter increment. Both effects disappear if the last period (85/95) for Plot I is excluded. So it is licit to work with one regression model for each set of inventories and plots, but excluded Plot I's 85/ 95 inventory period.

Thus the appropriate parameterisation of this function is:

$$
i_{\mathrm{d}}=b_{0}+b_{1} \times \ln \left(d_{\mathrm{i}}\right)+b_{2} \times(\mathrm{GCUM})^{3}
$$

where $i_{\mathrm{d}}$ is the diameter increment in mm, GCUM the stand density index in $\mathrm{m}^{2}$

parameters: $b_{0}=1.506969 ; b_{1}=0.942251 ; b_{2}=-0.000183455$

statistics: $R^{2}=0.881 F$ for $\ln \left(d_{\mathrm{i}}\right)=35.6 F$ for $\mathrm{GCUM}=12.8$.

Because the function contains GCUM, an indicator of stand closure, it is appropriate for modelling the influence of different stand structures on diameter increment, together with the model of determining steady state demographic distributions to use model (3).

\subsection{Removal}

Figure 5 depicts the course of the removal rate for the Langula beech plenter plots. Up to $d b h 50$ to 55 , removal is low and corresponds to minimal necessities for silvicultural care (selection and nurturing). From $d b h 60$ onward it grows exponentially to the target-harvesting diameter. To a large extent, this is consistent with observed interventions in classical plenter forests i.e. with data for the Les Erses beech plenter forest (Swiss Jura).

The $e_{\mathrm{i}}$ values can be estimated with a polynomic function:

$$
e_{\mathrm{i}}=b_{0}+b_{1} \times d_{\mathrm{i}}+b_{2} \times d_{\mathrm{i}}^{2}+b_{3} \times d_{\mathrm{i}}^{3}
$$

where $e_{\mathrm{i}}$ is the removal rate of each $d b h$-category, and $d_{\mathrm{i}}$ is the diameter at breast height of the category.

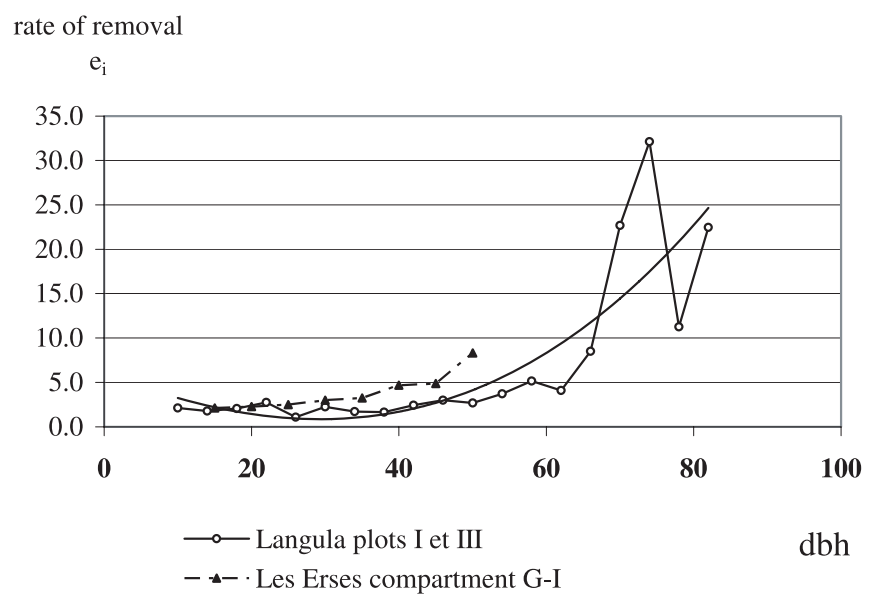

Figure 5. Removal rate $e_{\mathrm{i}}$ in relation to $d b h$ for Langula Plots I and III (and 4 periods), in Comparison to $e_{\mathrm{i}}$ for the Les Erses (Swiss Jura) beech-dominated plenter forest.

Parameters: $b_{0}=3.106927 ; b_{1}=-0.063725 ; b_{2}=-0.00237252$; $b_{3}=0.0073951692$.

Statistics: $R^{2}=0.807$.

\subsection{Equilibrium}

To determine the equilibrium stand density position and the corresponding equilibrium stem number distribution, it is necessary to calibrate the steady state stem number distribution so that its starting number of trees $\left(N_{10}\right)$ corresponds to real observed recruitment conditions. Conditionally it is necessary to consider the influence of stand density on the modelled steady state stem number distributions. So we simulate firstly (with function 3) different steady state distributions, starting with different arbitrarily $N_{\max }$ values, also using function (4) to determine incrementally the corresponding successive $i_{\mathrm{d}}$ values corresponding to the determined GCUM. $N_{10}$ results of this simulation (solid curve in Fig. 6) are presented on resulting basal area $(G)$ which is identical with the GCUM of the lowest $d$-class. The trend of observed $N_{10}$ data and corresponding $G$ is shown by the dotted line in Figure 6 . The $N_{10}$ value for equilibrium position lies at the intersection of the simulated trend and the trend line for observed data.

Fitted function for simulated $N_{10}$ values

$$
\begin{aligned}
N_{10} \text { simulated } & =511.72-58.998 \times G+1.8739 \times G^{2} \\
R^{2} & =0.992 .
\end{aligned}
$$

Fitted function for observed $N_{10}$ values (linear regression of real data of the plots I and III (excluding Plot II because ongoing recruitment was not assessed in the same way as for the two other plots) as well as two sets of data from Landbeck [12] valid for the Keula beech plenter forest (same region, north-east of the Thuringia basin).

$$
\begin{aligned}
N_{10} \text { observed } & =303.13-9.7132 \times G \\
R^{2} & =0.388
\end{aligned}
$$




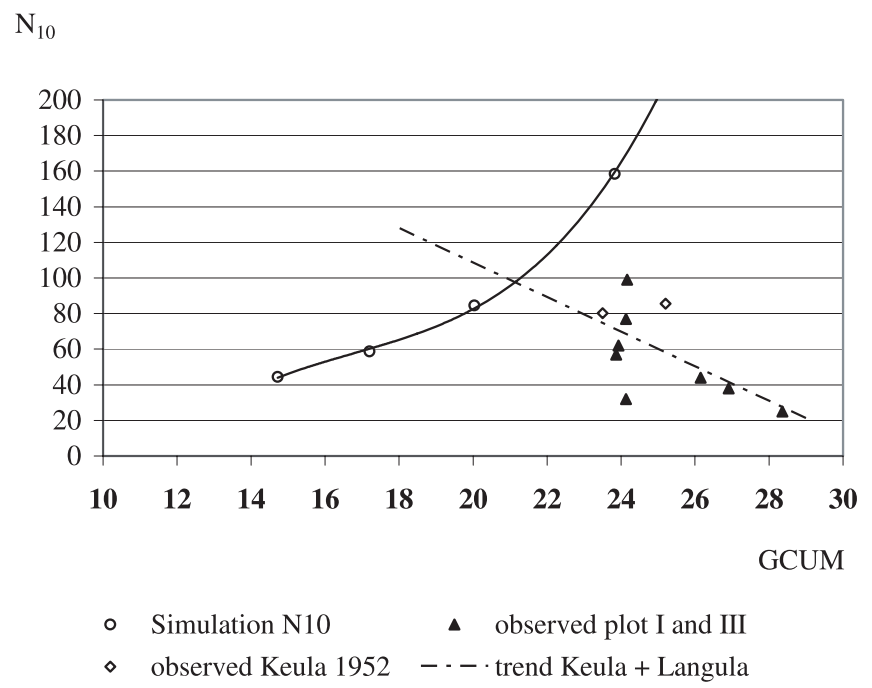

Figure 6. Observed and simulated relationship between trees in the lowest diameter-class $\left(N_{10}\right)$ and stand density in terms of basal area for determination of the real demographic equilibrium.

Intersection point (thus real $N_{10}$ equilibrium): $G: 21.99 \mathrm{~m}^{2}$; $N_{10}: 99.16$.

The equilibrium stem number distribution can be calculated incrementally using formula (2) and (4) starting from $N_{10}$ of the intersection point (Fig. 6). The corresponding equilibrium standing volume is $252.7 \mathrm{~m}^{3} / \mathrm{ha}(G=21.99)$.

The corresponding equilibrium volume increment is given by

$$
i_{\mathrm{V}}=\sum n_{\mathrm{i}} \times p_{\mathrm{i}} \times \delta \mathrm{v}_{\mathrm{i}}
$$

where $i_{\mathrm{V}}$ is the volume increment and $\delta \mathrm{v}_{\mathrm{i}}$ is the volume function differences from $d b h$ category to category.

It results an annual volume increment of $8.09 \mathrm{~m}^{3} / \mathrm{ha}$ and $\mathrm{y}$.

Figure 7 depicts the determined equilibrium stem number distribution for the Langula beech plenter forests. By way of comparison, the equilibrium stem number distribution of a classical (i.e. fir/spruce) plenter stand in the Swiss Pre-Alps is also shown. The equilibrium standing volume of beech plenter stands occurs at a far lower level $\left(254 \mathrm{~m}^{3} / \mathrm{ha}\right)$ than in classical plenter forest, as calculated for regions like Emmental ( $\left.413 \mathrm{~m}^{3} / \mathrm{ha}\right)$.

Figure 8 illustrates this difference in terms of the decrease in diameter increment with GCUM of the different diameterclasses in the case of equilibrium situations. Each point represents the diameter increment of the different diameter-classes. On the left, the largest $d$-class, on the right, the lowest. It shows the extinction of diameter increment with diminishing $d b h$.

\section{DISCUSSION}

The result - namely an equilibrium standing volume of $252.7 \mathrm{~m}^{3} /$ ha (correspond to $22 \mathrm{~m}^{2}$ basal area) - corroborates the empiric view of practitioners in the beech plenter forest in Thuringia [9, 12-15]. They all considered a standing volume $\mathrm{n} / \mathrm{ha}(\log )$

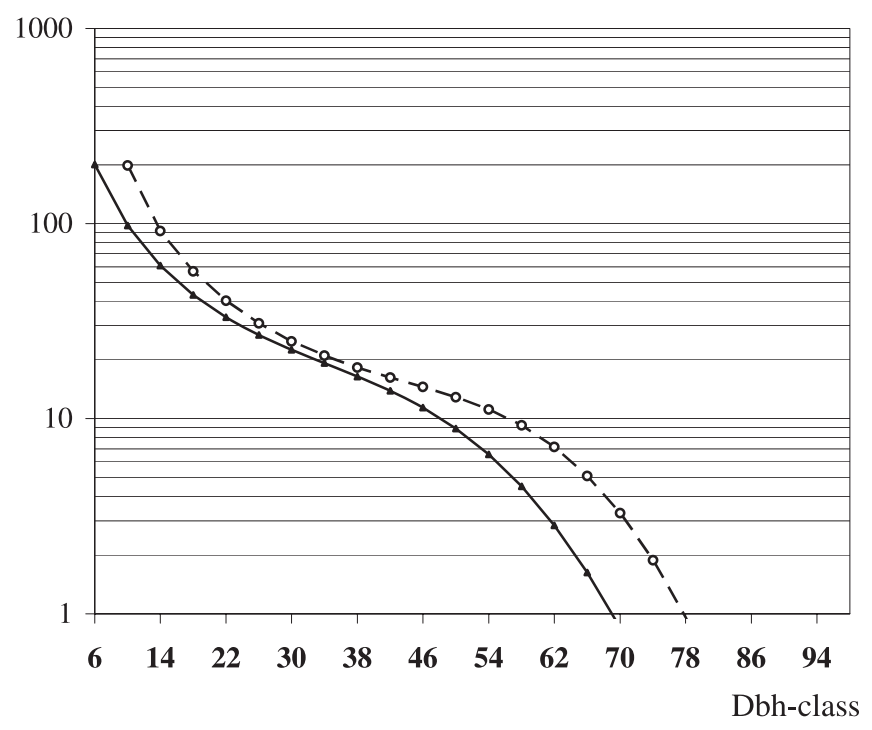

$$
\begin{aligned}
& \longrightarrow \text { equilibrium Langula } \\
& -\infty-\text { fir/spruce-Plenterforest Höhrone }
\end{aligned}
$$

Figure 7. Equilibrium stem number distribution for the Langula beech plenter forest compared to the equilibrium for a classical plenter forest i.e. a fir/spruce dominated stand. Here the demonstration plot for student training of ETH-Zurich at Höhronen (Swiss Prealps) at an altitude of $950 \mathrm{~m}$ a.s.l., equilibrium standing volume $413 \mathrm{~m}^{3} / \mathrm{ha}$.

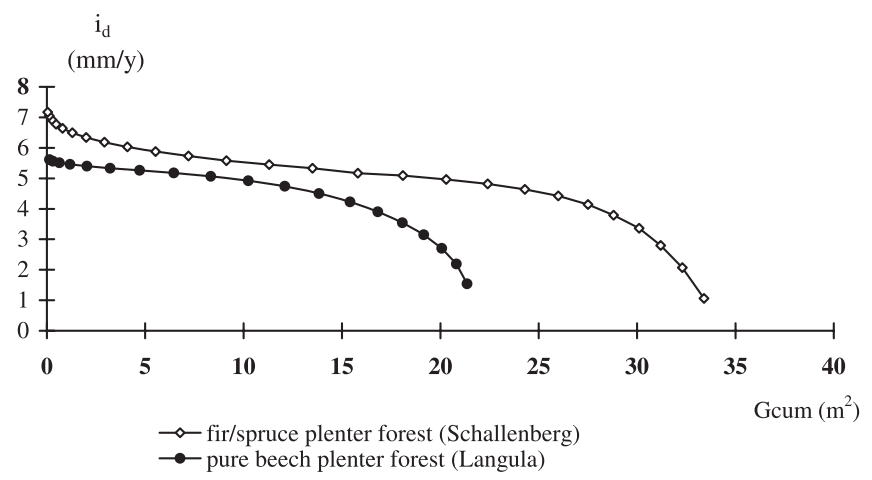

Figure 8. Decreasing diameter increment in equilibrium for beech plenter forests and for a classical fir/spruce plenter forest (Schallenberg, Emmental, Switzerland) vs. corresponding GCUM of the different dbh classes.

of about $250 \mathrm{~m}^{3} /$ ha to be the upper limit to maintain the plenter system in these pure beech stands. They also claimed that standing volumes of over $300 \mathrm{~m}^{3} /$ ha would be problematic for maintaining a vertical plenter structure in the long run. This equilibrium volume of $253 \mathrm{~m}^{3} /$ ha correspond to stem wood above $7 \mathrm{~cm}$ without branches. Corresponding equilibrium in terms of stem and branch volume above $7 \mathrm{~cm}$ is $306 \mathrm{~m}^{3} /$ ha (difference of $21 \%)$. 
Our results demonstrate a drastic and very clear reduction of the diameter increment of recruitment pole trees at a certain stand density, in this case, at about $24 / 25 \mathrm{~m}^{2}$ basal area (see Fig. 3). This corresponds to a standing volume of $280-290 \mathrm{~m}^{3} / \mathrm{ha}$, and signifies that at around this stand density, recruitment trees stop growing and the plenter structure is permanently lost. Schütz and Röhnisch [25] estimate in raw approximation that a diameter increment of $2 \mathrm{~mm} / \mathrm{y}$ is necessary to ensure acceptable recruitment in coniferous plenter forests. This clear position of growth extinction in relation to basal area should be considered as the carrying capacity for recruitment; it probably depends on a combination of factors acting on regeneration and growth under the canopy. This point also seems to be one of the most important criteria for demographic sustainability in plenter forest.

Because of its simplicity, another indicator of recruitment sufficiency for the practitioner is the demographically appropriate number of trees in the lowest diameter-class $\left(N_{10}\right)$. Here, for Langula the corresponding value was calculated to be $99 /$ ha for a $4 \mathrm{~cm} d$-class 8 to $12 \mathrm{~cm}$. When the $N_{10}$ value goes under this threshold, this implies that recruitment is insufficient to maintain on the long run structure stability and that it is necessary to reverse the tendency by reducing standing volume.

Figure 8 shows that the point of extinction of the diameter increment of recruitment poles for beech plenter forests occurs at a much lower standing volume than in classical fir/spruce plenter forests. This finding is of great importance. It means that the risk of surpassing the point of no return, where diminishing recruitment endangers demographic sustainability, is much higher in beech forests than in conifer-dominated ones. It also explains why there has been little or no success in the past when applying the principles of the plenter system to broad-leaved forests [17]. The reasons for this lay in the space occupancy from crown expansion behaviour [23]. Badoux [2] showed that for the same diameter, beech crowns in plenter forests is twice as large and so tend to occlude the canopy. For other broadleaves species the relationship of crown width in relation to spruce is 1.8 for ash and 2.2 for maple [25].

By discussing the characteristics of the presented model, it is emphasised that one of the most delicate points is the determination of silvicultural strategy for removal, in particular, target harvesting diameter. The definition of equilibrium characteristics depends on this particular variable. The concentration of the yield on large timber and consequentially the minimising of small timber is deemed to be one of the biggest advantages of the plenter system $[10,19]$. There are evidently limits to this advantage. One of these is the formation of discoloured wood (known as facultative red heartwood). Today, this is one of the main concerns for beech quality timber. Development of facultative red heartwood depends mainly on ageing and is closely related to large diameters $[5,11]$ especially if it displays pathological forms (so called spash heartwood; "Spritzkern"). Therefore, outsized timber should be avoided. This point should be considered when choosing the target harvesting dimension. A plenter system which tends to harvest beech with $d b h$ 55-60 is certainly possible, but as shown for conifers [16], the corresponding equilibrium standing volume would be significantly lower than that calculated here: $250 \mathrm{~m}^{3}$ per ha. The consequence of such light plenter structures on the development of undesirable features such as secondary crowns from epicormic branches should not be underestimated. According to Altherr and Unfried [1], a basal area of $21 \mathrm{~m}^{2}$ seems to be the threshold for developing and maintaining the epicormic branches in beech.

Acknowledgements: I am very grateful to Prof. G. Wenk, former director of the chair of forest yield science of the forestry school Tharandt, techn. Univ. Dresden (Eastern Germany), Prof. Röhle (actual director) and Mrs. Dr. Dorothea Gerold for allowing free use of the data of their Langula research plots and for advice, further information and interesting debate. Thanks to Andreas Zingg for allowing free use of the data from plenter research plots of the research institute forests snow and landscape (WSL) at Birmensdorf (Switzerland) and Mr. G. Ferrero and D. Horisgerger for allowing free use of the data from management plans Les Erses.

\section{REFERENCES}

[1] Altherr E., Unfried P., Zur Wasserreiser-Entwicklung bei der Buchen Lichtwuchsdurchforstung, Mitt. Forstl. Versuchs- u. Forschungsanst. Baden-Wurttemberg, 108 (1984) 59-65.

[2] Badoux E., L'allure de l'accroissement dans la forêt jardinée, Mitt. Schweiz. Anst. Forstl. Versuchsw. 26 (1949) 9-58.

[3] Borel W., Guide pour l'application du contrôle aux futaies jardinées, Jacques et Demontrond, Besançon, 1929.

[4] Borel W., Résultats de quarante ans d'application de la méthode du contrôle dans la forêt des Erses (Jura vaudois), Jacques et Demontrond, Besançon, 1933.

[5] Büren S. v., Der Farbkem der Buche (Fagus sylvatica L.) in der Schweiz nördlich der Alpen: Untersuchungen über die Verbreitung, die Erkennung am stehenden Baum und die ökonomischen Auswirkungen, Beiheft z. Schweiz. Z. Forstwes. 86 (2002) 1-137.

[6] Dittmar O., Untersuchungen in Buchen-Plenterwald Keula: Ein Vergleich zwischen den Buchen-Plenterwald Keula und dem gleichaltrigen Buchenhochwald anhand langfristiger Versuchsflächen, Forst u. Holz 45 (1990) 419-423.

[7] Gerold D., Zuwachs und Nutzung in Buchenplenterwäldern, in: Kenk G. (Ed.), Jahrestagung Dt. Verband Forstl. Forschungsanst. Sekt. Ertragskunde, Schwarzburg, 13-15 Mai 2002, pp. 33-42.

[8] Gerold D., Biehl R., Vergleich zwischen Buchenplenterwald und Buchenbetriebsklasse, Allg. ForstZ. 47 (1992) 91-94.

[9] Haselhuhn F., Buchenplenterwirtschaft in den Sonderhauser Hainleiteforsten, Forstarchiv 11 (1935) 17-24.

[10] Knoke T., Analyse und Optimierung der Holzproduktion in einem Plenterwald: Zur Forstbetriebsplanung in ungleichaltrigen Wälder, Forstl. Forschungsber. München 170/1998 (1998) 1-182.

[11] Knoke T., Schulz-Wenderoth S., Ein Ansatz zur Beschreibung der Wahrscheinlichkeit und Ausmass der Farbkernbildung bei Buche (Fagus sylvatica L.), Forstwiss. Centralbl. 120 (2001) 154-172.

[12] Landbeck H., Über die Buchenplenterwälder in Nordthüringen, Der Wald (Berlin) 2 (1952) 244-247 and 279-282.

[13] Matthes H., Der gemischte Buchenplenterwald auf Muschelkalk in Thüringen, Allg. Forst- u. J. Ztg. 86 (1910) 149-164.

[14] Schaber R., Waldbauliches aus Thüringen, Arbeiten der Thüringische Hauptlandwirtschaftskammer 16 (1933) 1-254.

[15] Schilling W., Studien aus den Buchen-Plenterwaldungen des Hainich, Forstwirtsch. Holzwirtschaft 4 (1949) 252-255.

[16] Schütz J.P., Dynamique et conditions d'équilibre de peuplements jardinés sur les stations de la hêtraie à sapin, Schweiz, Z. Forstwes. 126 (1975) 637-671. 
[17] Schütz J.P., Die waldbauliche Formen und die Grenzen der Plenterung mit Laubbaumarten, Schweiz. Z. Forstwes. 143 (1992) 442-460.

[18] Schütz J.P., Les problèmes et les limites des approches de recherche en production dans les peuplements mélangés et les peuplements irréguliers, in: Chhun-Huor Ung. (Ed.), Les modèles de croissance forestière et leurs utilisations, Colloq. Internat. 18-19 nov. 1993, Québec, Canada, 1993,pp. 97-111.

[19] Schütz J.P., Sylviculture 2: la gestion des forêts irrégulières et mélangées, Presses Polytechniques et Universitaires Romandes, Lausanne, 1997.

[20] Schütz J.P., Conditions of equilibrium in fully irregular unevenaged forests, in: Emmingham W.H. (Ed.), The state-of-the-art in European plenter forests: Proceedings of the IUFRO Interdisciplinary Uneven-aged Management Symposium, September 1997, Oregon State University, Corvallis, 1999, pp. 455-467.

[21] Schütz J.P., Bedeutung der Buchenplenterwälder Thüringens im Kontext zeitgemässer Waldbaukonzepte zur Förderung der Strukturvielfalt im Walde, in: Naturwald in Europa; Leitbild für den künftigen Nationalpark "Hainich", Naturschutzreport Nr. 16, Thüringer Landesamt für Umwelt, Jena, 2000, pp. 130-142.

[22] Schütz J.P., Der Plenterwald und weitere Formen strukturierter und gemischter Wälder, Parey, Berlin, 2001.

[23] Schütz J.P., Silvicultural tools to develop irregular and diverse forest structures, Forestry 75 (2002) 327-337.

[24] Schütz J.P., Barnola P., Importance de la qualité et de sa détermination précoce dans un concept d'éducation du hêtre, Rev. For. Fr. 48 (1996) 417-430.

[25] Schütz J.P., Röhnisch F., Steuerung des Nachwuchses während der Überführung von gleichförmigen Fichten Aufforstungsbeständen in Plenterwälder, in: Kenk G. (Ed.), Tagung der Sektion Ertragskunde des Deutschen Verbandes forstliche Forschungsanstalten, Torgau 2-4 Juni 2003, 2003, pp. 184-194.

[26] Wykoff W.R., Crookston N.L., Stage A.R., User's guide to Stand Prognosis Model, USDA Forest Service, General Technical Report [NT-133] Ogden, Utah, 1982. 